MAGDALENA KOWALSKA

ORCID: 0000-0003-4942-5598

\title{
KIEDY DEBIUT JEST POŻEGNANIEM OSTATNI MÓJ SONET NORWIDA I ADIEUX À LA POÉSIE LOUISE ACKERMANN
}

\section{Louise Ackermann, Adieux à la poésie}

Mes pleurs sont à moi, nul au monde

Ne les a comptés ni reçus;

Pas un œil étranger qui sonde

Les désespoirs que j'ai conçus.

L'être qui souffre est un mystère

Parmi ses frères ici-bas;

Il faut qu'il aille solitaire

S'asseoir aux portes du trépas.

J'irai seule et brisant ma lyre,

Souffrant mes maux sans les chanter,

Car je sentirais à les dire

Plus de douleur qu'à les porter ${ }^{1}$.

Tłumaczenie Gabriela Karskiego:

Pożegnanie poezji

Łzy moje do mnie tylko należą, Nikt ich nie pozna, nie zliczy, Żadne spojrzenia obce nie zmierzą Zrodzonej we mnie goryczy.

1 L. Ackermann, Euvres: ma vie, premières poésies, poésies philosophiques, Paris 2005, s. 3-4. 
Człowiek, co cierpi, jest tu na ziemi

Zagadką między sąsiady;

Musi drogami iść samotnymi

I siąść u progów zagłady.

Pójdę samotnie, lirę rozbiwszy,

Pieśnią mych trosk nie ogłoszę,

Bo wtedy ból mój byłby dotkliwszy

Od tego, z jakim je znoszę 2 .

W dotychczasowej refleksji nad twórczością Cypriana Norwida można znaleźć wiele przykładów studiów ujawniających pokrewieństwo myśli poety z koncepcjami francuskich autorówdrugiej połowy XIX stulecia. Prace Macieja Żurowskiego, Magdaleny Siwiec, Arenta van Nieukerkena, Piotra Śniedziewskiego, Wiesława Rzońcy i Anny Krasuskiej otworzyły inspirujące badawcze perspektywy - Norwid jawi się jako partner w dyskusji o pryncypiach sztuki z poetami francuskiego parnasizmu i symbolizmu. Trudno odnaleźć w równym stopniu interesujące konteksty dla twórczości autora Vade-mecum w poezji wczesnego francuskiego romantyzmu ${ }^{3}$. Dwa wiersze, autorstwa Norwida i Louise-Victorine Ackermann, z domu Choquet (1813-1890), które są przedmiotem interpretacji w niniejszym artykule, wydają się przynależeć do odrębnych światów - dzieli je płeć i narodowość poetów oraz uznanie dla ich dzieł w dawnej i współczesnej recepcji, a także poetycki styl i sposób wypowiedzi. Terenem, który umożliwia komparatystyczną próbę, jest natomiast miejsce utworów w drodze poetyckiej autorów - należą bowiem do pierwszych wierszy, które wyszły spod ich pióra - oraz narzucona już w tytule sytuacja ich odbioru jako ostatnich w ich twórczości w ogóle lub w pewnym jej wymiarze formalnym. Ostatni mój sonet Norwida ${ }^{4}$ i Adieux à la poésie Ackermann zaskakują czytelników zapowiedzią zakończenia dopiero co rozpoczętego etapu twórczości. O tradycji romantycznych pożegnań z ,poezją" lub z Muzą poety można mówić już w latach 30. dziewiętnastego wieku, jest sygnowana nazwiskami Byrona i Alphonse'a de Lamartine'a, ma potem

${ }^{2}$ L. AcKermann, Pożegnanie poezji, przeł. G. Karski, w: Antologia poezji francuskiej, red. J. Lisowski, t. 3, Warszawa 2000, s. 381. Istnieje też wcześniejsze, inne thumaczenie autorstwa Julii Dickstein-Wieleżyńskiej, w: L. ACKermann, Poezje, Lwów 1933, s. 71.

${ }^{3}$ Por. M. Kowalska, Xavier Forneret odczytany przez surrealistów i czytany Norwidem. „Przegląd Humanistyczny” 2017, nr 4, s. 173-184.

${ }^{4}$ Jest to sonet o niepewnym autorstwie. Edytorzy najnowszej, pierwszej krytycznej edycji wierszy Norwida w ramach Dzieł wszystkich, wydawanych przez Towarzystwo Naukowe KUL, włączają ten utwór do edycji. Cytując sonet, korzystam z wersji opracowanej do druku przez Profesor Grażynę Halkiewicz-Sojak, której dziękuję za udostępnienie wyniku jej pracy. 
wielkich kontynuatorów w postaci np. Théophile'a Gautiera ${ }^{5}$. Nie zdarza się jednak równie często taki gest w okresie poetyckiego debiutu. $Z$ oczywistych powodów wypowiedziom poetyckim Norwida i Ackermann, stylizowanym na „ostatni” przekaz liryczny, brakuje charakterystycznych dla „późnej poezji”, tak jak rozumie ją Anna Legeżyńska, wątków, np. egzystencjalnych obrachunków, powrotów do lat dzieciństwa, rozważania nieprzemijającego piękna sztuki ${ }^{6}$. Zapowiedzi wypowiedzenia się poetycko po raz ostatni i ostatniego użycia pewnych form poetyckich w pierwszych lirycznych utworach to nie jedyne wymagające namysłu aspekty dwóch analizowanych wierszy. Treść dzieł prowokuje do wielu pytań,. Ackermann nie używa słowa „poezja” w swoim utworze, tak jak w treści wiersza Norwida nie pojawia się słowo ,sonet” (także wspomniany utwór Byrona nie jest sonetem). Zanim Ackermann przedstawi siebie jako poetkę, upływają dwie z trzech strof jej utworu. Nieco inaczej ukazuje się problem pożegnania z pewnym typem twórczości w sonecie - Norwid już w trzecim wersie zapisał słowa o „mych pożegnań chwili”, a Ackermann porusza ten temat niezmiennie dopiero w trzeciej strofie. W lekturze wierszy ujawnia się więc przewrotność zamysłu sygnalizowanego przez autorów w tytułach. „Ja” liryczne obu utworów ujawnia zamiar zamilknięcia, lecz w sonecie Norwida padają słowa - są to właśnie słowa pożegnania, a Ackermann ten romantyczny gest wyjawia dopiero na końcu utworu. Informacja o prawdziwym obiekcie pożegnania - o rzeczywistym temacie utworu - została przez poetów zawoalowana, być może wiersze swoją strukturą i stylistyką mówią o nim w istocie więcej niż w warstwie przedstawieniowej. Hipotezą interpretacyjną w mojej analizie jest stwierdzenie Williama Marxa z pracy Pożegnanie z literatura. Historia dewaluacji od XVIII do XX wie$k u$. Zauważył on, że „pożegnanie z literaturą” to wygodny, użyteczny gest - najczęściej jego prawdziwą intencją jest pożegnanie pewnego etapu, na którym znalazła się współczesna autorom literatura, i którą uważają oni za literaturę par excellence $e^{7}$. Warto też przywołać uwagę w podobnym duchu Patricka Besniera i Claude'a Milleta o Lamartinie, w którego twórczości, jak przyznają, gest pożegnania z poezją pojawia się tak często, że może to przywodzić na myśl zachowa-

${ }^{5}$ M. SIwIEC, Romantyczne koncepcje poezji. Poeta i Muza - relacja w stanie kryzysu (Alfred de Musset i Juliusz Stowacki), Kraków 2012.

${ }^{6}$ A. LeGEŻyŃSKA, Gest pożegnania: szkice o poetyckiej świadomości elegijno-ironicznej, Poznań 1999.

7 W. MARX, L'Adieu à la littérature, Histoire d'une dévalorisation XVIIIe-XXe siècle, Paris 2005, s. 15: „Ainsi, quand il est ici question de l'adieu à la littérature, c'est par commodité d'expression: il s'agit en fait de l'adieu à un certain état de la littérature que les écrivains concernés considèrent à tort comme la littérature par excellence". 
nie maniakalne: „Pragnienie celebracji swoich pożegnań z poezją - zakończenia przygody z nią - jest u źródeł Lamartinowskiego współistniejącego pragnienia bycia poetą: pragnienia zaznaczenia dopełnienia w tym samym stopniu co przejścia do innych rzeczy, odpowiadających na potrzeby społeczne i polityczne"8. Być może więc analizowane utwory, niewyróżniające się typowo debiutanckim charakterem ani nienoszące znamion późnej poezji w największym stopniu przedstawiają $\mathrm{w}$ istocie przejście do kolejnego etapu twórczości, wydobycie się z ram narzuconych przez poetycką świadomość.

\section{„SAMOTNICZKA”}

Louise Ackermann datuje wiersz Adieux à la poésie na rok 1835, ale ukazał się on drukiem w jej tomie Contes et Poésies w dziale Premières Poésies w 1863 r., sonet Norwida zaś powstał w ostatnim kwartale 1839 r., a ukazał się w „Piśmiennictwie Krajowym” Hipolita Skimborowicza, literackim dodatku do „Gazety Porannej” (luty 1840, oddz. II, nr 8). Dłuższy czas między powstaniem a opublikowaniem wiersza w przypadku autorki wynika z jej losów. Wiersz powstał w Paryżu: w mieście, w którym Ackermann urodziła się, lecz we wczesnym dzieciństwie jej rodzina wyprowadziła się ze stolicy, aby wieść spokojny wiejski żywot w Pikardii. Poetka napisała utwór po powrocie do Paryża, w czasie, gdy pobierała nauki na pensji. Kolejne lata życia autorka spędziła w Berlinie, tam wyszła za mąż za językoznawcę Paula Ackermanna. Po kilku latach małżeństwa, zakończonego niespodziewaną śmiercią jej męża w młodym wieku, zamieszkała w Nicei, gdzie przebywała jej siostra, i spędziła tam resztę swojego życia ${ }^{9}$. W 1855 i 1862 r. wydano jej Contes en vers, ale dopiero publikacja tomu wierszy (obejmującego zarówno pierwsze utwory, jak i poezję filozoficzną) w 1874 r. przyniosła jej uznanie jako poetki. Należy zaznaczyć, że recenzje jej twórczości przypadają w okresie, kiedy francuska krytyka literacka ma za sobą doświadczenie komentowania

${ }^{8}$ P. Besnier, C. Millet, L'Éclatement poétique, w: Histoire de la France littéraire: Modernités, Paris 2006, s. 246: „Le désir de célébrer ses adieux à la poésie - d'en finir avec elle - est au fond chez Lamartine presque consubstantiel au désir d'être poète: désir de marquer un accomplissement autant que de passer à autre chose, répondant à une demande sociale et politique".

9 Fakty z życia autorki zaczerpnięte zostały z jej autobiografii Ma vie (L. ACKERMAnN, Euvres, s. III-XXIII). Polski przekład w tłumaczeniu autorstwa Julii Dickstein-Wieleżyńskiej można znaleźć w: L. Ackermann, Poezje, s. 53-70. Ponadto warto wspomnieć o thumaczeniu Ludwika Brunera szkicu o poetce autorstwa Anatole'a France'a: Pani Ackermann, w: tenże, Pisma krytyczne, Lwów 1904, s. 177-187. Tekst ten zawiera także krótką biografię poetki i opis spotkania $\mathrm{z}$ nią francuskiego pisarza i ich rozmowy o poezji. 
m.in. Kwiatów zła Charlesa Baudelaire'a, dyskutuje o ideach Pierre'a-Josepha Proudhona i Auguste'a Comte'a. Najbardziej entuzjastyczny wobec jej twórczości recenzent, Elme-Marie Caro, wskazywał, że „to, co odkryjemy w tej książce, to część duszy współczesnej, to jej duchowe poruszenie, jej wybuchy, a zarazem zniechęcenie" 10 - słowa te mogłyby stanowić komentarz wprost do analizowanego Pożegnania poezji. Warto jeszcze zaznaczyć, że także w polskiej recepcji pokoleniem, które odkryje twórczość Ackermann, będą najpierw autorki urodzone w latach 40. XIX wieku - pojedyncze utwory tłumaczą Maria Konopnicka ${ }^{11}$ i Eliza Orzeszkowa ${ }^{12}$ - a następnie w latach 60 . znajdziemy wzmianki o francuskiej poetce w Profilach poetów francuskich Zenona Przesmyckiego ${ }^{13}$ i w Ludziach bezdomnych Stefana Żeromskiego ${ }^{14}$.

\section{SYTUACJA LIRYCZNA I FORMA UTWORÓW}

W sonecie Norwida obraz sytuacji żegnania kobiety przez mężczyznę sugerowany jest już w pierwszym wersie, apostrofa do „Pani” pojawia się natomiast dopiero w wersie kończącym tetrastychy, ale ślad lirycznego „ty” wybrzmiewa także w wersie: „Póki jeszcze Twych spojrzeń jasność dla nas świeci”, mocno konstytuującym relację ,my”. Jest to istotna różnica w stosunku do sytuacji lirycznej w wierszu Ackermann. Samotność, którą poetka przedstawia w drugiej i trzeciej strofie, przede wszystkim poprzez przymiotniki „seule” i ,solitaire”, ujawnia się w porównaniu z wierszem Norwida także w tym, że w sytuacji lirycznej brakuje tak wyraźnego „ty”. W pierwszej strofie partnerują ,ja” lirycznemu tylko jakiś „nikt” oraz jakieś „obce oko” - nieokreśleni w żaden sposób, odpowiadający bezosobowemu światu. Druga strofa, przypominająca swoim charakterem maksymę, mówi o homo dolorosus, pokazując go najpierw wśród braci, następnie jako

${ }^{10}$ E. CARo, La Poésie philosophique dans les nouvelles écoles. Un poète positiviste, „Revue des Deux Mondes” 1874, vol. 3, s. 249: „c'est une partie de l'âme moderne que nous voyons à découvert dans ce livre, ce sont ses agitations morales, ses emportements et tout à côté ses découragements".

${ }_{11}$ M. Konopnicka, Wojna. Z poezyj Ludwiki Ackerman, w: L. ACKermann, Poezje, s. 135-140.

12 E. OrzeszKowa, Listy zebrane, t. 5, Wrocław 1961, s. 25-26 (thumaczenie utworu L'Amour et la Mort o incipicie: „O, skruszy się wkrótce ta glina...”).

13 Z. Przesmycki, Profile poetów francuskich, w: Wybór pism krytycznych, t. 1, Kraków 1967, s. 109: „Zupełnie osobno, jakby w oddali od wszystkich, ukazuje się postać wielkiej pesymistki, pani Ackermann".

${ }^{14}$ Fragment dziennika Joanny Podborskiej: „Czytam Ludwikę Ackermann” (S. ŻEromsKi, Ludzie bezdomni, Warszawa 1996, s. 67). 
samotnego człowieka. Kontrast zbiorowości i jednostki staje się jeszcze wyraźniejszy, gdy weźmiemy pod uwagę użyte określenie „parmi sesf rères”, a więc: „pośród swoich braci”, a nie np. „wśród ludzi”, które brzmiałoby bardziej neutralnie. Nie jest to jedyna klarowna opozycja w tej strofie, ponieważ „ici-bas” (,tutaj”) zderzone jest z kresem, śmiercią: „trépas”. Trzecia zaś transponuje ten uniwersalny obraz na oś życia osoby mówiącej w wierszu: to, co było powiedziane w zdaniu ogólnym, teraz jest wypowiedzią ,ja” lirycznego: „ll faut qu'il aille solitaire”- „J'irai seule”. W trzeciej strofie nie ma już żadnych śladów obecności innych osób. Warto też zaznaczyć, że wspomniany powyżej epitet „seule” jest jedynym słowem w utworze, dzięki któremu możemy zidentyfikować osobę mówiącą w wierszu jako kobietę ${ }^{15}$.

Sytuacja liryczna w analizowanych wierszach wpływa też na zakres obrazu świata: u Norwida, oprócz tego, że mamy przedstawioną relację między „ty” i „,ja” lirycznym (zaimki odnoszą się zarówno do pierwszej, jak i drugiej osoby liczby pojedynczej, np.,,mych pożegnań”, „Twe usta”, ale także do pierwszej osoby liczby mnogiej: „dla nas”, „o nas”), poeta sięgnął po motywy pejzażowe: wodę, w której przepływający obiekt pozostawia ślad, niebo zasnute czarnymi chmurami. Istnieją one jako człony porównania bądź jako odbicie pejzażu wewnętrznego, lecz w istotny sposób poszerzają granice świata utworu. Co więcej, mamy odwołanie do przeszłości, do poprzedników poety - do pożegnania Byrona - oraz dowiadujemy się o perspektywie przyszłości, o ,wróżeniu” przyszłych losów. W porównaniu z surowym stylem Ackermann, nasyconym przede wszystkim zaimkami pierwszej osoby liczby mnogiej: ,,je”, „moi”, „mes”," z nieobecnością konkretnego „ty” lirycznego, z brakiem odniesienia się do scenerii, w której następuje pożegnanie, sonet Norwida jawi się jako utwór nasycony przejawami rzeczywistości otaczającej osobę mówiącą w wierszu i adresatkę utworu.

Niewielka długość formy sonetu nie odpowiada długości jednostek go tworzących, są to bowiem zdania złożone, występuje tu wplecenie wypowiedzi innych osób, zacytowanie ich - słów Byrona i wyobrażonej reakcji ukochanej na pożegnanie - oraz zwielokrotnienie jednego sposobu rozpoczynania wypowiedzi, przez „póki” i „może”. Kiedy już dochodzi do wypowiedzenia na głos formuły pożegnania, okazuje się ona dłuższa i bardziej patetyczna od lakonicznego „Bądź zdrowa”, z którym osoba mówiąca w wierszu starała się skontrastować swoje po-

${ }^{15}$ Już w XIX-wiecznej krytyce literackiej upowszechnił się osąd autorki jako głosu ,niekobiecego”, por. J. Barbey D’AuREvilly, Les Poètes, Paris 1889, s. 159: „C'est l'homme, ici, qui a chanté comme aurait pu chanter la femme, et la femme, comme l'homme n'a pas chanté".

${ }^{16}$ Marie Delcourt i Dorothée Costa zwracają uwagę, że ,ja” liryczne całkowicie przejmuje władanie nad większością utworów Ackermann (Préface, w: L. Ackermann, CEuvres, s. ii). 
żegnanie, zapewniając też, że jego chwila będzie „oniemiałą”. Zauważmy, że sposób rozstania z pierwszego wersu wydaje się być zarezerwowany dla wyjątkowo niewdzięcznych zachowań lub dla pożegnania w konflikcie. Osoba mówiąca w wierszu odrzuca ten sposób, pragnie pożegnać się w milczeniu, korzystając jedynie z wymownego spojrzenia - co zakłada bliskość tak fizyczną, jak i emocjonalną uczestników sytuacji. Ostateczne wypowiedzenie słów pożegnania odbywa się w specjalnych okolicznościach, w unikalnym kontekście, na co wskazuje poeta w konstrukcji: „teraz [...] póki jeszcze”. Jest ona wieloznaczna, można ją tłumaczyć jako: ,póki nie nadejdzie chwila zwątpienia w stałość uczucia ukochanej”, zważywszy na początek utworu, ale też prawdopodobnie jako: „Póki trwa nasza niczym niezmącona zażyłość”, „póki dana nam jest nasza miłość”, odnosząc się do wersów drugiej strofy. Wskażmy jeszcze jeden aspekt kontrastu między bajronicznym pożegnaniem, a tym ,ja” lirycznego: to pierwsze stało się już pewną konwencją, dość rozpowszechnioną, czego świadoma jest osoba mówiąca w wierszu: ,tak [...] tak i niejeden” [uwypuklenie moje - M.K.]. Być może zatem nie jest tu tylko wydobyta różnica między słowem a milczeniem, lecz przede wszystkim wypowiedzią $\mathrm{w}$ ramach towarzyskich i poetyckich ram pożegnania, ale nie żywą i szczerą, lecz spetryfikowaną, pozbawioną znaczenia a gestem poety, który ma ujawniać prawdziwość intencji.

Większy stopień kondensacji komunikatu osiągnęła Ackermann, w której utworze nie ma powtórzeń oraz mnogości epitetów, tak wyraźnej w sonecie Norwida: ,ponury”, „niestała”, „,czarne” itd. Poetka wykorzystuje natomiast repertuar wyrazów bliskoznacznych, odnoszących się do smutku, beznadziei - w wierszu w oryginalnym języku występują one w liczbie mnogiej, co potęguje odczucie przytłoczenia tymi emocjami w porównaniu do jednego „,je”: „Mes pleurs”, „Les désespoirs”, „mes maux”. Wszystkie te stany noszą wyraźne znaki przynależności do jednej osoby: zaimki „mes” oraz zdanie podrzędne: „que j'ai conçus”, co sugeruje, że rozpacz nie jest po prostu uniwersalnym wydźwiękiem utworu, lecz przede wszystkim bije ona ze źródła - z odczuć osoby mówiącej w wierszu.

Mimo że forma sonetu narzuca rygor w ekspresji myśli i między strofą pierwszą a ostatnią można mówić tylko o zmianie długości strofy, to w utworze Norwida jest zauważalne, że na początku wiersza wypowiada się osoba w stanie wzburzenia emocjonalnego, natomiast $\mathrm{w}$ toku utworu zachodzi zmiana $\mathrm{w}$ stronę łagodzenia toku wypowiedzi. Gwałtowność pierwszej strofy uwidacznia się w obrazie płomieni (pojawiających się w kontekście oczu - zatem kontrastujących ze spokojną ,jasnością spojrzeń” z drugiej strofy). Gest pożegnania jest w niej zwielokrotniony - czasownik ,żegnał” został użyty w aspekcie niedokonanym, tak, jak gdyby czynność wciąż była ponawiana, a poeta używa liczby mnogiej rzeczownika „pożegnanie”. „Oniemiała chwila” może oczywiście oznaczać najprościej 
chwilę milczenia, jednak może być to również personifikacja chwili, która zaniemówiła tak, jak ktoś czymś przestraszony lub zaskoczony, „struchlała”. Drugi wers nie wymaga orzeczenia, ponieważ pada ono w pierwszym wersie, jednakże poprzez użycie anadiplozy: „luby, lubą” i wyrazów rozpoczynających się od nie- na obrzeżach wersu: „,niejeden”-,,niestałą” sprawia wrażenie bardzo zamkniętej konstrukcji jego pozbawionej. Ponadto „zawsze”, kończące pierwszą strofę, a powtórzone jeszcze potem w wierszu kilka razy, kontrastuje z łagodnym obrazem przemijania: ,jak ślad łodzi płynącej”, pojawiającym się na końcu utworu. Repetycyjność „,zawsze” traci stopniowo na sile w toku utworu - dość mocno wybrzmiewa ono w słowach pożegnaniach ,ja" lirycznego, ale potem, w powtórzeniu w ustach kobiecych, nabiera tonacji łagodnego żalu, pogodnego smutku. Sonet Norwida ilustruje zatem większą skalę emocji niż jednostajny w swoim nastroju rozpaczy wiersz Ackermann. Można tę konstatację zilustrować jeszcze jednym aspektem utworów. Szczęście jest elementem przyszłości jednej osoby w sonecie Norwida („losy szczęście Ci wywróżą”), na przeciwległym krańcu mamy wizję o kontrastowym charakterze: ,zasłona przyszłości czarnych chmur nie wznieci”. U Ackermann nazwy stanów emocjonalnych: „pleurs” z pierwszego wersu utworu i „douleur” z ostatniego okazują się rymem wewnętrznym, obrazującym stałą tonację utworu. Zauważmy jednak, że po wyciszeniu w środkowej strofie o charakterze uniwersalnym następuje gest również bardzo gwałtowny i zarazem kluczowy dla utworu o ,pożegnaniu poezji”.

\section{LIRY ŚPIEWAJĄCE I ZŁAMANE}

Na dookreślenie sytuacji pożegnania czytelnik wiersza Ackermann czeka aż do rozpoczęcia trzeciej strofy, do słów „brisant ma lyre”. To symboliczne przedstawienie zakończenia poetyckiej twórczości było bardzo popularne w wielu epokach i w różnych kulturach narodowych. W tradycji polskiej motyw odwieszenia lub zniszczenia instrumentu, atrybutu poety, zyskał własne znaczenie w poezji porozbiorowej. W kulturze francuskiej epoki romantyzmu świadectwa złamania liry związane są z topiką poety umierającego, jak u Lamartine'a:

La lyre en se brisant jette un son plus sublime,

La lampe qui s'éteint tout à coup se ranime,

Et d'un éclat plus pur brille avant d'expirer ${ }^{17}$.

17 A. de Lamartine, Le Poète mourant, w: Méditations poétiques, CEuvres poétiques complètes, éd. M-F. Guyard, Paris 1963, s. 144. Utwór był tłumaczony na język polski m.in. przez Franciszka Ksawerego Godebskiego, Franciszka Salezego Dmochowskiego, Ludwika Kamińskie- 
Roztrzaskana lira ma być zatem posłańcem jeszcze jednego, wyjątkowego poetycko dźwięku. Ackermann sięgnęła po ten motyw także w innym utworze. W wierszu Lira Orfeusza, zamieszczonym również w Premières Poésies, tytułowy obiekt unosi się na wodzie, a grają na nim powiewy wiatru i fale wody. Za sprawą tej muzyki przybywa personifikacja wiosny, a nagie brzegi rzeki pokrywają się kwieciem. Wiersz kończy się refleksją o współczesnej poetce epoce wypływającą z wykrzyknienia:

Ah! que nous sommes loin de ces temps de merveilles!

Les ondes, les rochers, les vents n'ont plus d'oreilles,

Les cœurs mêmes, les cœurs refusent de s'ouvrir,

Et la lyre en passant ne fait plus rien fleurir ${ }^{18}$.

Kluczowy dla analizy wiersza Adieux à la poésie jest tu motyw serc, które odmawiają otwarcia. Negatywna ocena świata ludzi i ludzkiego pojmowania nieszczęścia, a także możliwości porozumienia duchowego z innym, jest sugerowana w sformułowaniach o „œil étranger qui sonde” i w doborze słownictwa dla opisu sposobów poznania przez ludzi - wskazują one na racjonalny charakter oglądu: „compter”, „recevoir”, „sonder”. Nieco inny komponent znaczeniowy ma sentencja zamieszczona w Pensées d'une solitaire: „Le poète a d'abord été un initiateur; aujourd'hui il n'est plus qu'un écho"'19.

Motyw roztrzaskanej liry oraz negatywnej oceny działań innych, obecny we wspomnianych powyżej tekstach Ackermann, przywodzi z kolei na myśl jeszcze jeden Norwidowski tekst, poemat Quidam, w którym Zofia tuż przed śmiercią tak ostrzega Artemidora:

go. Są to jednak, zgodnie z podtytułami, „,naśladowania” - u Godebskiego układ strof nie odpowiada temu z oryginalnego utworu. Dokładniejsze jest tłumaczenie Dmochowskiego, który tak przekłada te wersy: „Z milszym, z szczytniejszym dźwiękiem, lutnia się roztrąca, / Na chwilę się rozjaśnia lampa konająca, / I czystszego nam światła przed zgonem użyczy" (Pisma wierszem, Warszawa 1827, s. 118). W utworze Lamartine'a wspomniana jest także m.in. harfa eolska jako instrument poety, a rola cierpienia symbolicznie przedstawionego w tym fragmencie jest odmienna od tej wspomnianej przez Ackermann: „Ma harpe fut souvent de larmes arrosée, / Mais les pleurs sont pour nous la céleste rosée; / Sous un ciel toujours pur le cœur ne mûrit pas”.

18 Thumaczenie Julii Dickstein-Wieleżyńskiej (L. Ackermann, Poezje, s. 84):

Ach, dla nas czasy cudów gdzież się zapodziały?

Dziś już nie mają uszu fale, wiatry, skały,

Nawet serca daremnie otwierać pragniecie,

I gdy lira przepływa, nic nie staje w kwiecie.

19 L. Ackermann, Pensées d'une solitaire, Paris 1903, s. 8. 
Liry mi z sobą nie unieś, bo jęknie -

Podsłyszą szpiegi, co się w lirze chowa,

Rozbiją na krzyż, że każda z strun pęknie,

Spadkami pękań tych wyrzekłszy słowa

Wszystkiego - co jest na świecie coś warte -

A ludzie patrzeć będą, jak ta mowa

Odleci w lazur, pierś mając rozdartą.

I jeszcze o drachm założa się pare,

Czy też do Grecji szczątki jej doleca? -

(DW III, 282)

Kilka wersów później wspomniany w tym locie jest m.in. właśnie Orfeusz. „Szpiegi” odgrywają podobną rolę, co „obce oko” w wierszu Ackermann - próbują dotrzeć do tego i usłyszeć to, co kryje się w poezji - jednak w Quidamie to oni rozbijają lirę, żeby wydrzeć tę tajemnicę, podczas gdy utworze francuskiej autorki to sama „poetessa” w akcie desperacji tego dokonuje. Ludzie wspomniani przez Zofię nie rozumieją nic z przesłania płynącego z liry - widzą tylko jego zewnętrzne, powierzchowne właściwości. Temat odległości, jaką pokonają szczątki liry, rozważany przez odbiorców, współgra z oceną płaczu w utworze Ackermann przez obce osoby, które próbują „zebrać” i „zliczyć” nieszczęście ,ja” lirycznego - nie ma tu natomiast mowy o zrozumieniu. Sytuację poetyckiego natchnienia i wymarzonego wpływu na słuchaczy przedstawiał wcześniejszy fragment Quidama, improwizacja Zofii - w którym również pojawia się lira. Ostatnia strofa jej poetyckiej kreacji brzmi:

Bo inna pojać wzór i, cało-dźwięków tworu

W po-za-jawie słuchając, nad światy,

Samemu kwiatem wzrość, ku prawdzie pierwowzoru,

A inna — wieniec wić — lub rwać kwiaty — -

Jakja" -

Wtedy poetessa odkłada lirę, lecz ona wydaje jeszcze dźwięk poezji:

— dodała wieszczka, kładąc lirę,

Głosem, co echa nie miał, lub nieszczere,

Gdy strun ostatnie dźwięki, coraz letsze,

Strofę tę jeszcze powtarzały w wietrze:

„Bo inna pojąć wzór - i, cało-dźwięków tworu

W po-za-jawie słuchając, nad światy, 
Samemu kwiatem rość, ku prawdzie pierwowzoru,

A inna — wieniec wić — lub rwać kwiaty" — -

Syn Aleksandra, bardzo zadziwiony

Patrzył, na Zofii postać niepodobną

Do siebie samej, gdy za nią te tony

Rzuconej liry, na ławę osobną,

Odbrzękiwały jeszcze w cztery strony.

A postać wieszczki z nich rosnąć się zdała,

Jakoby z kręgu fali poruszonej

I szła ku gościom, blednąc — przy tym drżała,

[...]

Drżenie zaś takie, że jest z wysilenia,

By drugim swego udzielić natchnienia

I podnieść masę słuchaczy ku sobie,

Szybko się innym udziela, [...].

(DW III, 209-210)

Tony rzuconej liry odbrzękują w cztery strony, tak jak w późniejszym wyobrażeniu Zofii lira rozbita będzie na krzyż. We fragmencie mowa jest o „udzielaniu natchnienia drugim” i o tym, aby „Podnieść masę słuchaczy ku sobie” - tymczasem w marzeniu ludzie tylko obserwują i komentują zewnętrzne możliwości dźwięków, nie docierając do treści komunikatu poetyckiego, mówiącego o najważniejszych wartościach, tak jak w wierszu Ackermann cierpienie jednego z ludzi pozostaje tajemnicą dla drugich. Instrument z utworu Lira Orfeusza Ackermann we współczesnej epoce nie ma już takiej mocy, aby dzięki niemu zakwitnął świat. Zofia odczuwa brak w swojej poezji, który w podobny sposób jest opisany - prawda pierwowzoru to dla niej poezja Orfeusza i Homera, chciałaby takim kwiatem zakwitnąć, ,cało-dźwięków tworu” słuchając i dojrzewając do własnej wielkości poetyckiej.

\section{TEMATYKA - KONKLUZJE}

Podsumowując, należy powiedzieć, że Ackermann w większym stopniu spełnia zapowiadany w tytule zamiar przedstawienia pożegnania się z poezją - jej wiersz wyjaśnia przyczynę tego rozstania i ilustruje sam akt zakończenia poetyckiej działalności. Warto podkreślić, co rozumie francuska autorka pod pojęciem poezji. Bycie poetą oznacza dla niej: „chanter, dire mes maux”. Jest to 
stały element jej świadomości poetyckiej ${ }^{20}$ - paradoks stanowi jedynie to, że choć w utworze otwierającym jej Premières Poésies ujawnia, że jest to zadanie zbyt trudne, by je znieść, niemal w całej swojej dojrzałej twórczości porusza głównie temat cierpienia ${ }^{21}$.

Przyczyny dramatycznego gestu wydają się być dwie: niepogłębianie zakorzenionego smutku oraz nienarażanie się na niezrozumienie innych. Zauważmy, jak blisko niektóre ujęcia Ackermann sytuują się innego sonetu Norwida, Samotność. „Gdy dusza duszy pojąć, zrozumieć niezdolna”22- ten wers streszcza rozumienie ludzkich więzi także przez francuską poetkę. Opisuje ona przecież nieudolność w zrozumieniu cierpień drugiego człowieka. Norwid jednak wskazuje bardziej na ciężar pewnych towarzyskich konwenansów, na „katusze” uczestniczenia w życiu, którego przejawami są „,biesiada”, ,piosnka”, „uśmiech”, „gwar”, podczas gdy poetka z konieczności w samotności przeżywa swe cierpienie. „Ja” liryczne sonetu wybiera stan, w którym doświadcza tak pożądanej ciszy (wykreowanej zarówno przez brak ,z zewnątrz”: wrażeń symbolizujących towarzyskie

${ }^{20}$ Ackermann w swojej autobiografii cytuje fragment utworu napisanego w 1830 r., odpierając zarzuty, że jej pesymizm jest naśladowczy w stosunku do zainteresowań epoki, np. myślą Arthura Schopenhauera. W polskim thumaczeniu brzmi on następująco:

Pod klęsk brzemieniem ciało sterane się kruszy;

Chłonąc w nocy zwiastuńcze wieczności spokoje

Oko Twe wreszcie w grobu zamyka się głuszy:

Raduj się starcze, to jest pierwsze szczęście twoje.

(L. Ackermann, Poezje, s. 67).

Jeżeli upatrywać jakiegoś rodzaju naśladowania w twórczości poetyckiej Ackermann, to szukać źródeł należałoby w roku 1829, w którym przybyła do Paryża i który sama określiła jako moment ,pełnego rozkwitu romantyzmu” w stolicy Francji (L. Ackermann, Ma vie, s. V: „C'était en 1829, c'est-à-dire en pleine floraison romantique", spisane w Nicei 20 stycznia 1874 r.). Były to zarazem lata lektur Szekspira, Byrona, Goethego i Schillera - według słów Ackermann ci autorzy otworzyli jej „nowy świat poetycki” (tamże, s. VI: „un nouveau monde poétique”, spisane w Nicei 20 stycznia $1874 \mathrm{r}$.).

${ }^{21}$ Jak wskazywał Francisque Sarcey, cytując w swoim artykule w całości analizowany wiersz Ackermann, to w pieśniach o rozpaczy widać największe zaangażowanie poetki, a utwór ten nadaje ton całemu tomowi (Poètes contemporaines.,,Le XIXe siècle”, 25.08.1874). Współczesna badaczka Elena Thuault tak opisuje istotę poezji Ackermann: „La souffrance physique ou morale, le gouffre/l'abîme, c'est-à-dire la chute et l'anéantissement hérités du thème de l'ange déchu des romantiques, et enfin la mort, avec la répétition du lexique « cercueils », « tombeaux », « tombe ", constituent l'essence de ses thèmes, ainsi basée sur les douleurs et les épreuves qu'affronte l'Homme dans sa vie"(E. Thunult, Analyse critique de la poésie de Louise Ackermann, w: Les Galets de la mer: d'après l'œuvre de Louise Ackermann, Paris 2015, s. 86).

${ }^{22}$ Korzystam z wersji opracowanej przez Grażynę Halkiewicz-Sojak. Jest to kolejny sonet, którego autorstwo przypisał Norwidowi Juliusz Gomulicki. 
spotkanie, jak i brak głosu własnego: „urok milczenia czuję”) i w którym doznaje prawdziwej wolności.

Obraz człowieka siedzącego pod bramą śmierci, wzbudzającego litość swoją mizerną, bezradną kondycją, kontrastuje z dość gwałtownym gestem osoby mówiącej w wierszu, jakby zrywającej się do ostatecznego czynu: ,pójdę”, ,rozbijając". Warto przypomnieć w tym miejscu jeden z fragmentów poetki zebranych w tomie Pensées d'une solitaire: „Quand le poète chante ses propres douleurs il doit avoir la note sobre. Les cris personnels déchirants ne sont pas faits pour la poésie. Comme la Niobé antique, elle doit avoir la grâce de la douleur"23. Postać z drugiej strofy przypomina właśnie rzeźbiarskie przedstawienie, jej obraz kończy się statycznie, pozostaniem u progów, zastygnięciem. Prawdziwy temat utworu w przypadku Ackermann to poezja, która mogłaby służyć ekspresji uczuć, jest jednak w tym celu defektywna - nadawcy przysparza cierpienia, a odbiorcy, do których dociera, nie potrafią zgłębić tajemnicy nieszczęścia drugiego człowieka.

Zapomnienie jest udziałem obu osób sytuacji lirycznej w sonecie Norwida: „pamięć o nas zginie”. Takie sformułowanie na końcu wiersza mocno utrzymanego w konwencji liryki miłosnej, z jej toposami dotyczącymi opisu kobiecej urody, przedstawiać może niepowodzenie podobnych zabiegów poetyckich. Zwróćmy uwagę na dopisek: „Piątek o $5 \mathrm{z}$ rana” - w sonecie przedstawiającym ukochaną w słowach o ,jasności spojrzeń”, o „łezce”, ,marzeniach”, a wspominającym także o łaskawym wyroku niebios dla zakochanych, nie sposób nie pamiętać o dniu, w którym piękne oczy Laury spętały Petrarkę - mamy tu wyraźne powtórzenie derywatów od liczebnika „pięć”. Poezja Petrarki miała ocalać od zapomnienia ukochaną i jej anielskie oblicze - u Norwida zapowiedź „ostatniego” sonetu wydaje się korespondować z zakwestionowaniem tak ważnej roli tego typu liryki.

\section{ZAKOŃCZENIE}

Ackermann w większym stopniu odnosi się w swoim wierszu do poezji i aktu pożegnania się z nią niż Norwid do sonetu explicite. Utwór w całości przekazuje jednak więcej o jego świadomości konwencji formy sonetowej i gestów pożegnania z ukochaną niż Ackermann wyraziła wprost w krótkim utworze. Poetka żegna się z poezją jednym symbolicznym gestem - Norwid stylem całej tej wypowiedzi poetyckiej. Z późną poezją w rozumieniu Legeżyńskiej łączą autorów tylko ślady „ciemnego przeczucia kresu” w wersach: „A zasłona przyszłości czarnych chmur nie wznieci” oraz „I siąść u progów zagłady”. Norwid rzeczywiście daje ostatnie

${ }^{23}$ L. Ackermann, Pensées d'une solitaire, s. 21. 
świadectwo tego stylu poetyckiego w tym utworze, Ackermann rozważania o cierpieniu, które nie pozwala być poetką, przekuwa raczej w swoją poetycką siłę.

Przeprowadzona analiza porównawcza nie przekonała natomiast $\mathrm{w}$ zupełności o możliwościach owocnych prac nad zbliżeniem poezji Norwida z utworami wczesnego francuskiego romantyzmu. Kazus Ackermann jest bowiem wyjątkowy - późny debiut autorki i recenzje jej twórczości przypadające na lata, kiedy krytyka literacka używa pojęć „,poezja” i „,cierpienie” w nowych ujęciach w porównaniu do epoki romantycznej, to okoliczności, które pozwalają o niej mówić, tak jak jeden z krytyków, jako o poète moderne. Uderzające jawi się podobieństwo idei Adieux à la poésie z przesłaniem utworu Charles'a-Marie Leconte de Lisle'a Pokazywacze (Les Montreurs), pochodzącego z tomu Poèmes barbares, wydanego rok wcześniej niż Contes et Poésies Ackermann, powszechnie uznanego za krok odejścia od koncepcji poezji jako ekspresji uczuć. Przyczyną tej zmiany jest niechęć do wystawiania na publiczny widok uczuć dręczących ,ja”:

Ja, dumny, zmilknę w grobie, z daleka od chwały.

Bodaj ciemności wieczne z sobą mnie porwały,

Jeśli ci sprzedam ból mój, moje upojenie! ${ }^{24}$

Poeta nie chce ,żebrać o pospolitą litość” („,mendier ta pitié grossiére”) przypadkowej publiczności a przyszłość jawi mu się w podobnych barwach, co Ackermann, jako „czarna wieczność” („,l'éternité noire”). Powróciliśmy zatem jednak do rozważań nad zbieżnością myśli Norwida z debatą o poezji drugiej połowy XIX wieku.

\section{BIBLIOGRAFIA}

Ackermann L., Euvres: ma vie, premières poésies, poésies philosophiques, Paris 2005.

Ackermann L., Pensées d'une solitaire, Paris 1903.

Ackermann L., Pożegnanie poezji, przeł. G. Karski, w: Antologia poezji francuskiej, red. J. Lisowski, t. 3, Warszawa 2000.

Besnier P., Millet C., L'Éclatement poétique, w: Histoire de la France littéraire: Modernités, Paris 2006.

Delcourt M., Costa D., Préface, w: L. Ackermann, Euvres: ma vie, premières poésies, poésies philosophiques, Paris 2005.

LEgEŻyńsKa A., Gest pożegnania: szkice o poetyckiej świadomości elegijno-ironicznej, Poznań 1999.

Marx W., L'Adieu à la littérature, Histoire d'une dévalorisation XVIIIe-XXe siècle, Paris 2005.

${ }^{24}$ Ch.-M. Leconte DE Lisle, Pokazywacze, przeł. K. de Obaldia, w: Antologia poezji francuskiej, s. 397. 
SiwIEc M., Romantyczne koncepcje poezji. Poeta i Muza - relacja w stanie kryzysu (Alfred de Musset i Juliusz Stowacki), Kraków 2012.

Thunult E., Analyse critique de la poésie de Louise Ackermann, w: Les Galets de la mer: d'après l'œuvre de Louise Ackermann, Paris 2015.

\title{
KIEDY DEBIUT JEST POŻEGNANIEM. OSTATNI MÓJ SONET NORWIDA I ADIEUX À LA POÉSIE LOUISE ACKERMANN
}

\section{Streszczenie}

W artykule przedstawiono interpretację porównawczą utworów: Ostatni mój sonet Cypriana Norwida i Adieux à la poésie Louise Ackermann. Autorów dzieli płeć i narodowość, a także styl artystyczny oraz krajowa i europejska recepcja, ich wiersze powstały w odstępie czterech lat. Te dwa utwory okazują się interesującym materiałem do badania z powodu ich jednoczesnego debiutanckiego i „późnego” charakteru: opisano w nich gesty pożegnania z poezją w ogóle i w pewnym jej wymiarze. Obecność samotniczej egzystencji ,ja” lirycznego w wierszu Ackermann oraz jednostajnie smutnego nastroju w tym utworze, a relacji między ,ja" i ,ty" lirycznym w utworze Norwida oraz większej skali emocji prowadzi do wniosków, że tym, co łączy omawiane dzieła, jest motyw ludzkiej obojętności wobec uczuć innych i niezrozumienia ich poezji przez odbiorców. U Ackermann dominuje lęk przed tym brakiem współodczuwania, Norwida zaś uwypukla problem konwencji, które uniemożliwiają prawdziwą komunikację. Udowodniono zatem hipotezę, że tym, co w istocie żegnają w swoich debiutach twórcy, są tylko pewne właściwości poezji typowe dla liryki im współczesnej (ekspresja uczuć osoby mówiącej w wierszu, konwencje sonetowej liryki miłosnej), a utwory te stanowią przejście do innego etapu ich poetyckiej kreacji.

Słowa kluczowe: Louise Ackermann (1813-1890); parnasizm; debiut; pożegnanie; sonet; lira.

\section{WHEN EVERY DEBUT IS A FAREWELL. “OSTATNI MÓJ SONET” BY NORWID AND “ADIEUX À LA POÉSIE” BY LOUISE ACKERMANN}

\begin{abstract}
This article offers a comparative interpretation of two poems: "Ostatni mój sonet" [My Last Sonnet] by Cyprian Norwid and "Adieux à la poésie" by Louise Ackermann. Although these two authors differ in terms of sex, nationality, artistic style as well as the national and European reception of their work, these two poems are only four years apart. Both prove to be interesting material for study due to their simultaneous "debut" and "late" character: they describe gestures of bidding farewell to poetry in some specific aspect and in general. The lonely existence of the lyrical "I" in Ackermann's poem and its sombre mood can be juxtaposed with the relation between "I" and "you" and the increasing scale of emotions in the lyric by Norwid, leading to the conclusion that both works elaborate on the theme of human indifference to the feelings of others, and on the misunderstanding of both authors' poems by their readers. What dominates
\end{abstract}


in the case of Ackermann is the fear of lack of empathy, while Norwid emphasizes the problem of conventions that hinder real communication. What this is proves is that in these "debuts" the two authors bid farewell only to certain properties of poetry characteristic of the period's lyricism (expression of the feelings of the lyrical subject and the convention of sonnet-like love lyricism), while these two poems themselves open passages to different stages of poetic creation.

Translated by Grzegorz Czemiel

Key words: Louise Ackermann; Parnassianism; debut; farewell; sonnet; lyre.

MAGDALENA KOWALSKA - doktor nauk humanistycznych w zakresie literaturoznawstwa, autorka książek Prowansja w pismach polskich romantyków (2015) i Litanic Verse III: Francia (2018), pracownik Instytutu Literaturoznawstwa UMK; lena_k@wp.pl. 